\title{
Pemodelan Unified Modeling Language Sistem Informasi Enterprise Resource Planning
}

\author{
Fatmasari $^{1}$, Siti Sauda ${ }^{2, *}$ \\ ${ }^{1}$ Fakultas Ilmu Komputer, Program Studi Sistem Informasi, Universitas Bina Darma, Palembang, Indonesia \\ ${ }^{2}$ Fakultas Ilmu Komputer, Program Studi Teknik Informatika, Universitas Bina Darma, Palembang, Indonesia \\ Email: ${ }^{1}$ fatmasari@binadarma.ac.id, ${ }^{2, *}$ siti_sauda@binadarma.ac.id \\ Email Penulis Korespondensi: siti_sauda@binadarma.ac.id
}

\begin{abstract}
Abstrak-Pemodelan merupakan salah satu teknik yang digunakan untuk menggambarkan bagaimana sistem informasi akan dibuat dan dihasilkan. Pemodelan sendiri dapat dijadikan acuan dalam proses pengembangan sistem infromasi agar sesuai dengan kebutuhan pengguna. Salah satu teknik pemodelan yang sering digunakan adalah menggunakan unified modeling language (UML). Teknik pemodelan dengan UML mampu untuk menggambarkan berbagai macam fitur dari sistem informasi. untuk itu di dalam penelitian ini dilakukan pemodelan untuk sitem informasi enterprise resource planning (ERP) PTPN VII sebagai langkah awal pemenuhan kebutuhan pengelolaan informasi. penggunaan pemodelan sendiri dilakukan merupakan inisial awal implementasi teknologi informasi dan sistem informasi di lingkungan perusahaan terutama PTPN VII. Hasil dari pemodelan yang telah dilakukan menggunakan tiga jenis diagram pada UML sebagai acuan dalam pengembangan yaitu structure diagram yang dibuat menggunakan class diagram, behavior diagram yang dibuat menggunakan use case diagram, dan interaction diagram yang dibuat menggunakan activity diagram. Hasil pemodelan juga telah diimplementasikan ke dalam bentuk prototype sistem infromasi sehingga memberikan gambaran yang jelas bagi pihak yang berkepentingan jika akan dilakukannya pengembangan sistem infromasi enterprise resource planning (ERP) terutama di lingkuangan PTPN VII. Prototype sistem informasi juga dapat menggambarkan bentuk awal bagi pemangku kepentingan jika ingin dilakukan perubahan.
\end{abstract}

Kata Kunci: Pemodelan, UML, Sistem Infromasi, ERP, PTPN VII

Abstract-Modeling is one of the techniques used to describe how information systems will be created and produced. Modeling itself can be used as a reference in the process of developing information systems to suit user needs. One modeling technique that is often used is to use a unified modeling language (UML). Modeling techniques with UML are able to describe various features of information systems. for this reason, in this research a model for the PTPN VII enterprise resource planning (ERP) information system is used as an initial step in fulfilling information management needs. the use of modeling itself is an initial implementation of information technology and information systems in a corporate environment, especially PTPN VII. The results of modeling have been done using three types of diagrams in UML as a reference in the development of structure diagrams created using class diagrams, behavior diagrams created using use case diagrams, and interaction diagrams created using activity diagrams. The results of the modeling have also been implemented in the form of a prototype of the information system so as to provide a clear picture for interested parties if the development of enterprise resource planning (ERP) information systems, especially in the PTPN VII environment. The information system prototype can also describe the initial forms for stakeholders if changes are to be made.

Keywords: Modeling, UML, Information System, ERP, PTPN VII

\section{PENDAHULUAN}

Teknologi informasi (TI) dan sistem informasi (SI) saat ini telah digunakan hampir di semua aspek kehidupan. Penggunaan TI/SI sendiri dilakukan untuk meningkatkan produktifitas dari sebuah instansi atau perusahaan. Untuk itu tidak sedikit dari perusahaan mengalokasikan dana khusus yang akan digunakan untuk TI dan SI di lingkungan atau aktivitas perusahaannya. Kondisi tersebut juga terjadi di berbagai sektor baik perusahaan yang dimiliki oleh pemerintah maupun swasta. Lingkungan atau kalangan perusahaan badan usaha milik negara penggunaan TI/SI merupakan salah satu faktor penting dalam mendukung keberhasilan perusahaan. Kondisi tersebut terjadi pada perusahaan PTPN VII, perusahaan ini dibentuk dari berbagai perusahaan yang terdiri dari "PT. Perkebunan X (Persero) di Provinsi Lampung dan Sumatera Selatan, PT. Perkebunan XXXI (Persero) Provinsi Lampung dan Sumatera Selatan, Proyek Pengembangan PT. Perkebunan XI (Persero) di Kabupaten Lahat Provinsi Sumatera Selatan, dan Proyek Pengembangan PT. Perkebunan XXIII (Persero) di Provinsi Bengkulu". Pendirian perusahaan PTPN VII sendiri sesuai dengan Permen nomor 12 tahun 1996. PTPN VII sendiri merupakan perusahaan yang bergerak di bidang sawit, karet, teh dan gula.

Penggunaan teknologi untuk produksi pada PTPN VII saat ini sudah sangat baik, namun penggunaan TI/SI di lingkungan PTPN VII sendiri saat ini belum begitu maksimal, terutama pengelolaan informasi. Pengelolaan informasi dalam bidang permintaan produksi, penjualan dan pengiriman. Kondisi saat ini yang terjadi dalam melakukan pengelolaan data informasi permintaan, penjualan dan pengiriman telah menggunakan komputerisasi namun belum secara sistem, dimana alat bantu yang digunakan yaitu microsoft office, excel dan aplikasi lainnya yang tidak terintegrasi satu sama lain. Kondisi tersebut tentunya akan membutuhkan waktu dalam proses pengelolaan informasi permintaan, penjualan dan pengiriman. Selain itu juga hal yang tak kala penting adalah proses pelaporan, dengan kondisi seperti saat ini proses pelaporan informasi kepada pihak terkait akan memakan 
waktu dan tenaga yang tidak sedikit. Sedangkan jika dibandingkan dengan penggunaan TI/SI akan menjadi lebih mudah untuk dilakukan, karena dapat dilakukan secara sistematis dan terintegrasi.

Sesuai dengan kondisi tersebut maka perlu dilakukan tindakan awal sebagai langkah percepatan implementasi TI/SI di lingkungan PTPN VII, tindakan yang paling relevan untuk dilakukan yaitu melakukan pemodelan informasi yang dapat mengakomodasi kebutuhan dalam bidang permintaan, penjualan dan pengiriman. Salah satu tindakan yang memungkinkan yaitu dengan menerapkan Enterprise Resource Planning (ERP). enterprise resource planning $(E R P)$ sendiri merupakan aplikasi yang disediakan untuk perusahaan yang bergerak dalam bidang manufaktur atau jasa, enterprise resource planning $(E R P)$ juga dalam implementasinya dilakukan secara modular namun terintegrasi satu sama lain [1]. Saat ini terdapat berbagai macam aplikasi enterprise resource planning (ERP) yang disediakan diantaranya adalah Odoo, Odoo adalah adalah aplikasi yang dirancang dengan fitur untuk mengatur berbagai aktivitas yang ada pada perusahaan. Odoo sendiri merupakan aplikasi yang dikembangkan dari Open ERP [2]. Selain Odoo terdapat juga aplikasi yang dikhususkan untuk enterprise resource planning (ERP) yaitu Open Bravo, Open Bravo juga salah satu aplikasi yang banyak digunakan untuk mengimplementasikan enterprise resource planning (ERP). Open Bravo pertama kali dikembangkan di Barcelona yang merupakan salah satu enterprise resource planning $(E R P)$ terbaik ketika diluncurkan, aplikasi ini juga dibuat secara modular dan berbasis web [3].

Aplikasi enterprise resource planning (ERP) yang dikemukakan diatas merupakan aplikasi yang dapat diimplementasikan secara custom, sehingga ketika ingin digunakan harus menyesuaikan fitur dan fungsi yang ada pada aplikasi enterprise resource planning (ERP) tersebut. Untuk itu didalam penelitian ini akan dilakukan pemodelan sistem informasi enterprise resource planning (ERP) yang dapat diimplementasikan sesuai dengan kebutuhan dan keadaan lapangan di PTPN VII, sehingga sebelum dilakukan pengembangan sistem informasi enterprise resource planning $(E R P)$ dilakukan pemodelan. Pemodelan sendiri dilakukan sebagai langkah awal atau blueprint [4] dari sistem informasi enterprise resource planning (ERP) yang akan dikembangkan. Pemodelan juga digunakan untuk menyederhanakan permsasalah dalam pengembangan sistem informasi [5]. Untuk menggambarkan atau membuat pemodelan sistem infromasi salah satu alat bantu yang dapat digunakan yaitu unified modeling language (UML). UML sendiri memiliki kemampuan untuk menggambarkan atau memetakan kebutuhan sistem informasi dan UML juga bukanlah sebuah bahasa pemrograman [6]. Diagram yang terdapat pada UML sendiri terdapat berbagai jenis diagram yang dibagi menjadi tiga jenis yaitu structure diagram, behaviour diagram dan interaction diagram [7]. Sesuai dengan latar belakang yang telah dikemukakan sebelumnya maka dalam penelitian ini dilakukan pemodelan sistem informasi enterprise resource planning (ERP) menggunakan unified modeling language $(U M L)$. Dengan harapan hasil dari pemodelan yang dilakukan dapat digunakan dalam proses pengembangan. Selain itu juga pada penelitian ini dilakukan proses pengembangan prototype sistem informasi enterprise resource planning (ERP) dengan fitur utama permintaan, pemasaran dan pengiriman sebagai langkah akhir proses pemodelan sistem informasi.

\section{METODE PENELITIAN}

Dalam melakukan pemodelan unified modeling language sistem informasi enterprise resource planning metode penelitian yang digunakan yaitu metode deskriptif, metode deskriptif sendiri merupakan metode dengan kemampuan untuk menjelaskan fenomena atau keadaan berdasarkan pandangan peneliti [8]. Metode deskriptif juga memiliki kemampuan untuk menyajikan fakta atau kejadian dari prosedur penelitian sesuai dengan pandangan peneliti [9]. Sedangkan dalam melakukan penelitian langkah-langkah yang dilakukan seperti yang terlihat pada Gambar 1.

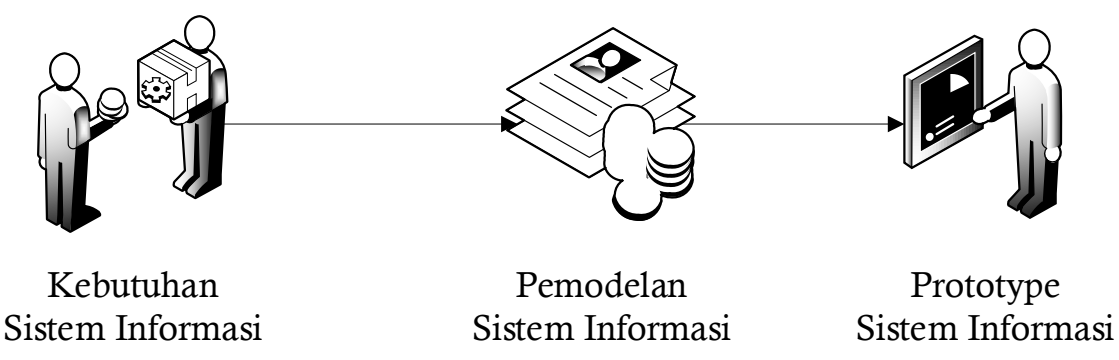

Gambar 1. Langkah Penelitian

Dari Gambar 1 dapat dilihat bahwa dalam melakukan pemodelan unified modeling language (UML) sistem informasi enterprise resource planning $(E R P)$ terdapat tiga langkah yaitu penentuan kebutuhan sistem informasi, melakukan pemodelan sistem informasi dan pembuatan prototype sistem informasi. Fase penentuan kebutuhan sistem informasi dilakukan identifikasi kebutuhan yaitu berupa proses permintaan produksi, penjualan dan pengiriman. Fase pemodelan sistem informasi dilakukan pemodelan menggunakan unified modeling language $(U M L)$. Dalam proses pemodelan ini digunakan tiga jenis diagram yaitu behavior diagram, interaction diagram 
dan communication diagram. Sedangkan prototype sistem informasi adalah proses pembuatan prototype dari sistem informasi berdasarkan hasil pemodelan sistem informasi.

\section{HASIL DAN PEMBAHASAN}

Sesuai dengan metode langkah-langkah penelitian yang telah dijelaskan maka proses yang dilakukan yaitu menentukan kebutuhan informasi yang akan disajikan dalam sistem informasi enterprise resource planning (ERP). Kebutuhan informasi tersebut yaitu meliputi proses permintaan produksi, penjualan dan pengiriman yang dapat dilakukan secara integrase satu sama lain. Dari kebutuhan informasi tersebut maka dilakukan pemodelan menggnakan unified modeling language (UML). unified modeling language (UML) merupakan alat perancangan sistem yang berorientasi pada ob UML didasari oleh konsep yaitu konsep permodelan Object Oriented (OO), karena konsep ini merupakan sistem seperti kehidupan nyata yang didominasi oleh obyek dan dinotasikan dalam simbol yang cukup spesifik maka Object Oriented (OO) memiliki proses standard dan bersifat independent. Unified modeling language (UML) diagram mempunyai tujuan yakni untuk membantu tim pengembangan proyek berkomunikasi, mengeksplorasi potensi desain, dan memvalidasi desain arsitektur perangkat lunak atau pembuat program. Notasi UML diturunkan dari 3 (tiga) komponen yang telah ada sebelumnya yaitu Grady Booch, OOD (Object-Oriented Design), Jim Rumbaugh, OMT (Object Modelling Technique), dan Ivar Jacobson OOSE (ObjectOriented Software Engineering). Unified modeling language (UML) memiliki tiga kategori utama yaitu structure diagram, behaviour diagram dan interaction diagram, dimana masing-masing kategori tersebut memiliki diagram yang menjelaskan arsitektur sistem dan saling terintegrasi. Untuk itu berikut dapat dijelaskan pemodelan yang dilakukan untuk masing-masing jenis diagram.

\subsection{Pemodelan Structure Diagram}

Pemodelan structure diagram merupakan pemodelan yang digunakan untuk melihat bagaimana struktur sistem informasi dibuat [10]. Untuk itu pada pemodelan sistem informasi enterprise resource planning (ERP) pada PTPN VII ini digunakan class diagram sebagai salah satu diagram yang ada pada structure diagram. Class diagram sendiri dibentuk dari tiga komponen utama yaitu nama kelas, atribut kelas dan method kelas, dimana nama kelas digunakan sebagai identitas kelas, atribut class digunakan sebagai identitas kelas dan method class digunakan sebagai tindakan yang dapat dilakukan class [11]. Gambar 2 dapat dilihat merupakan class diagram yang dibuat untuk sistem informasi enterprise resource planning (ERP).

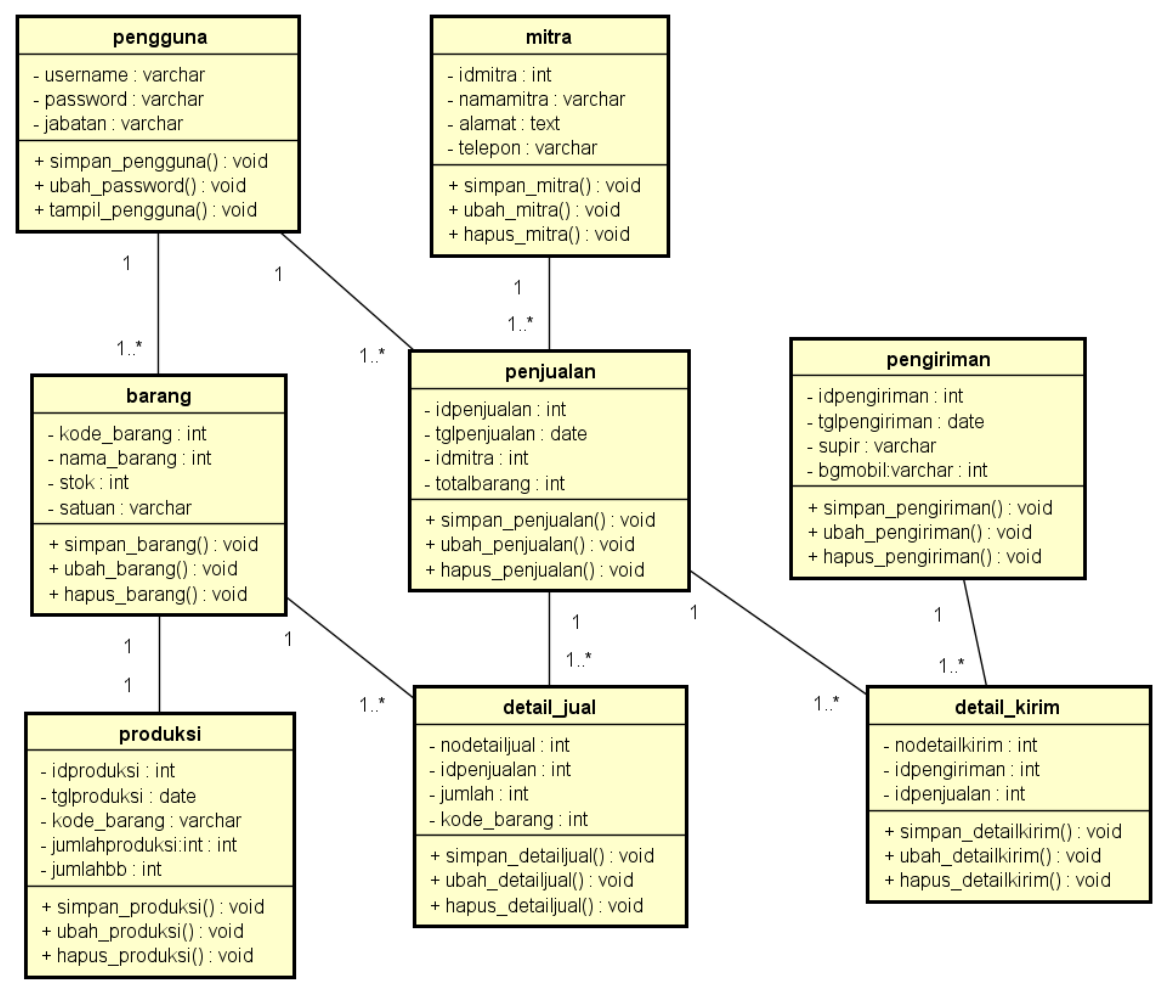

Gambar 2. Class Diagram Sistem Informasi 
Sesuai Gambar 2 dapat diketahui bahwa terdapat delapan class sebagai pembentuk sistem informasi yaitu class pengguna yang terdiri dari tiga atribut dan tiga method, class mitra yang terdiri dari empat atribut dan tiga method, class barang yang terdiri dari empat atribut dan tiga method, class penjualan yang terdiri dari empat atribut dan tiga method, class pengiriman empat atribut dan tiga method, class produksi yang terdiri dari lima atribut dan tiga method, class detail jual yang terdiri dari empat atribut dan tiga method, dan class detail kirim yang terdiri tiga atribut dan tiga method.

\subsection{Pemodelan Behavior Diagram}

Pemodelan behavior diagram adalah pemodelan yang dibuat untuk memberikan gambaran abstraksi sistem informasi yang akan dihasilkan. Salah satu diagram yang ada pada behavior diagram yaitu use case diagram [12]. Use case diagram meruapakan diagram yang mampu menggambarkan atau mengilustrasikan keterkaitan sistem informasi dan aktor atau pengguna dari sistem informasi [13]. Gambar 3 dapat dilihat merupakan use case diagram untuk sistem informasi enterprise resource planning (ERP) PTPN VII.

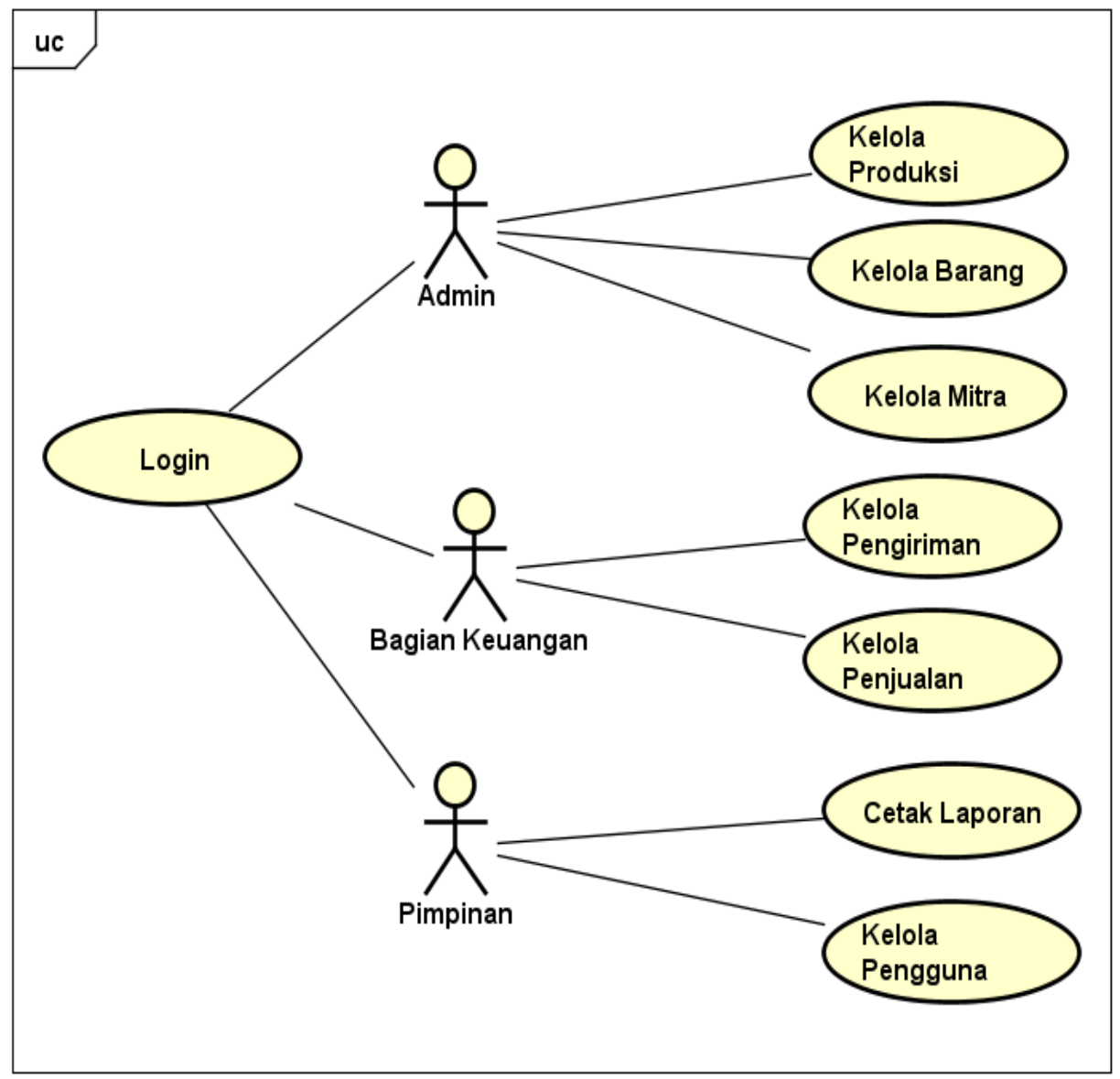

Gambar 3. Use Case Diagram Sistem Informasi

Gambar 3 merupakan use diagram yang menggambarkan tingkah laku pengguna terhadap sistem informasi enterprise resource planning (ERP). Terdapat tiga aktor yang berinteraksi yaitu bagian admin, bagian keuangan dan pimpinan. Bagian admin dapat melakukan pengelolaan data produksi, data barang, dan pengelolaan data mitra. Bagian keuangan dapat melakukan pengelolaan data pengiriman dan data penjualan. Pimpinan dapat melakukan pengecekan laporan dan pengelolaan data pengguna sistem informasi enterprise resource planning (ERP).

\subsection{Pemodelan Interaction Diagram}

Pemodelan interaction diagram merupakan diagram dinamik yang mampu menggambarkan bagaimana interaksi antar objek dalam sebuah sistem informasi [14]. Interaction diagram juga mampu untuk menampilkan objek dan aktor yang saling berinteraksi pada sistem informasi [10]. Pemodelan interaction diagram yang digambarkan untuk sistem informasi enterprise resource planning (ERP) yaitu menggunakan activity diagram. Activity diagram adalah diagram yang dapat menampilkan prosedur logika dan proses bisnis dalam sebuah sistem informasi. Gambar 4 dapat dilihat activity diagram untuk pengguna dengan akses administrator. 
ISSN 2614-5278 (media cetak), ISSN 2548-8368 (media online)

Available Online at https://ejurnal.stmik-budidarma.ac.id/index.php/mib DOI 10.30865/mib.v4i2.2022

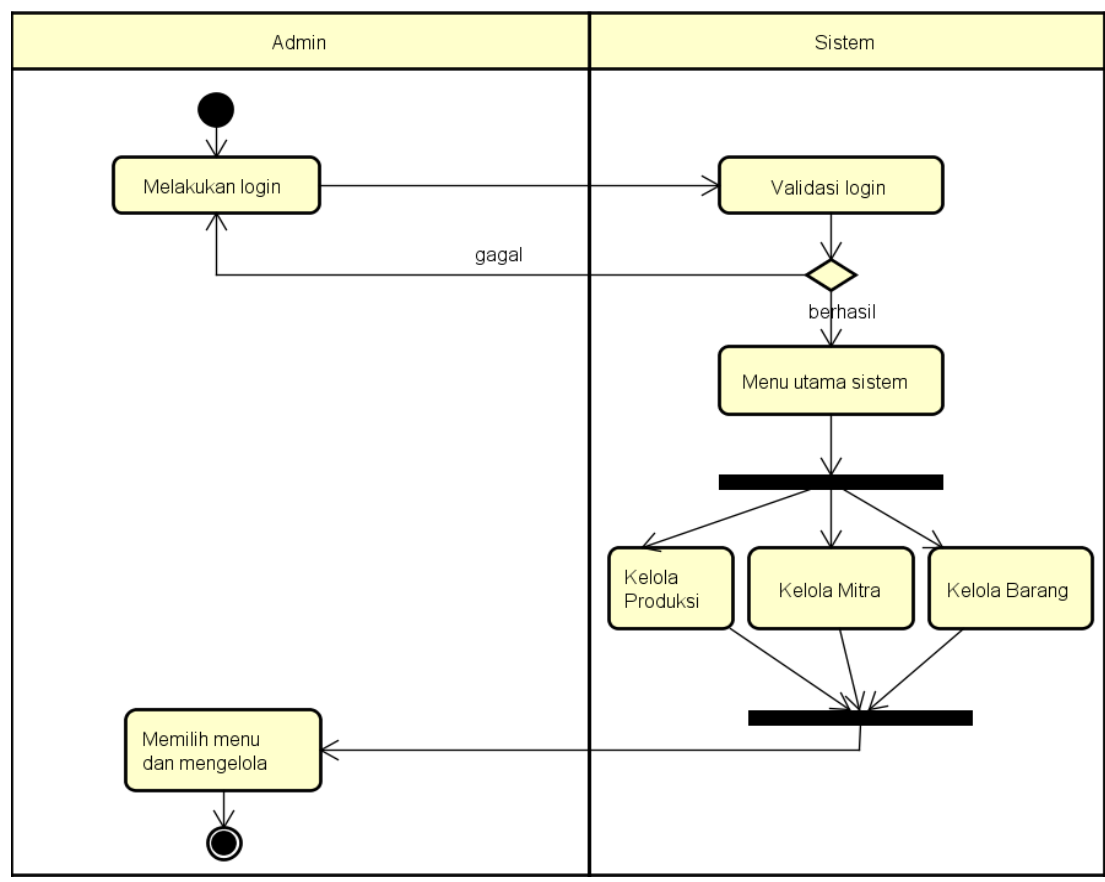

Gambar 4. Activity Diagram Admin

Sesuai dengan Gambar 4 bahwa pengguna dengan hak akses admin memiliki aktivitas dimulai dari melakukan login kemudian dilakukan validasi oleh sistem informasi. setelah sukses melakukan login maka akan ditampilkan menu utama dari sistem informasi dan dapat melakukan aktivitas mulai dari pengelolaan data produksi, pengelolaan data mitra dan pengelolaan barang. Selanjutnya pada Gambar 5 merupakan activity diagram untuk bagian keuangan. Seperti halnya pada activity admin untuk melakukan aktivitas pada sistem informasi enterprise resource planning $(E R P)$ harus dimulai dari login dan barulah kemudian dapat melakukan aktivitas. Aktivitas yang dapat dilakukan oleh bagian keuangan diantaranya adalah melakukan pengelolaan data penjualan dan pengelolaan data pengiriman barang.

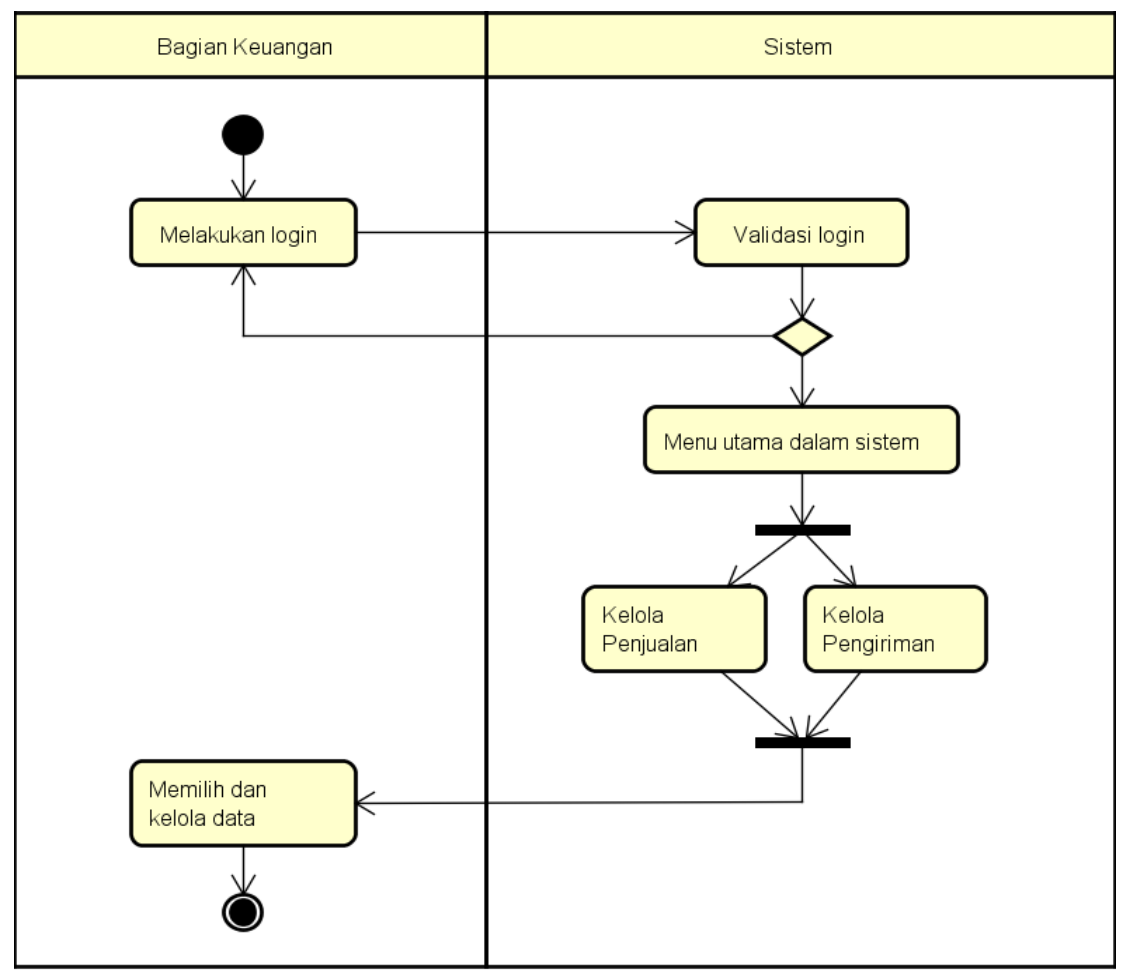

Gambar 5. Activity Diagram Bagian Keuangan 


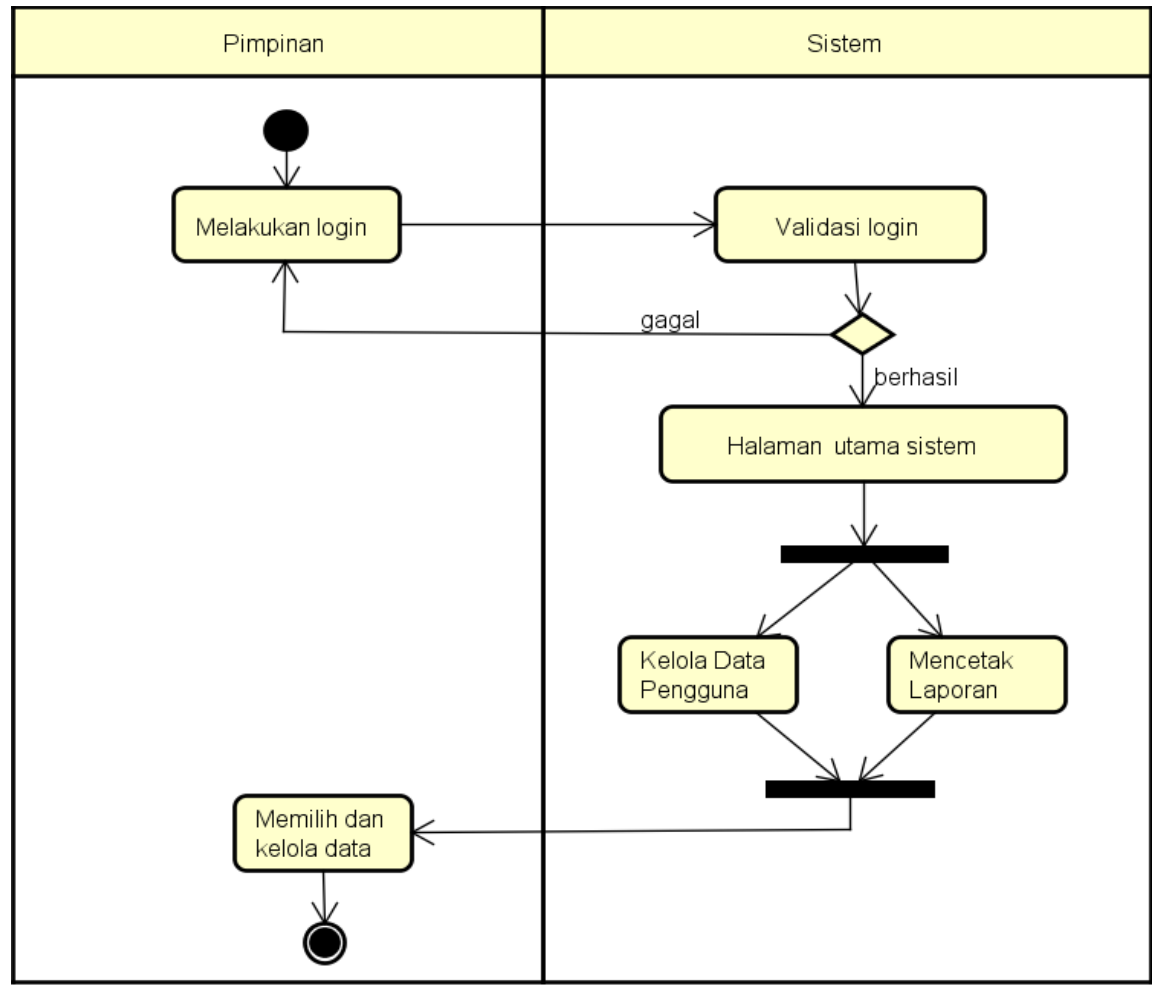

Gambar 6. Activity Diagram Pimpinan

\subsection{Prototype Sistem Informasi}

Setelah melakukan pemodelan sistem informasi enterprise resource planning $(E R P)$ dilakukan pengembangan prototype sistem informasi. Prototype sitem informasi dibuat dengan tujuan agar proses implementasi dari pemodelan data digambarkan dengan jelas. Prototype sendiri meruapakan versi awal dari sistem infromasi enterprise resource planning (ERP) PTPN VII yang akan dihasilkan. Dengan adanya prototype sistem informasi maka gambaran bagaimana sistem informasi yang akan dihasilkan memiliki gambaran yang nyata bagi pengguna. Selain itu juga dengan adanya prototype sistem informasi dapat dilakukan penyesuaian jika dianggap perlu bagi pengembang dalam proses pengembagnan sitem informasi [15]. Gambar 7 dapat dilihat tampilan untuk administrator sistem informasi yang dihasilkan berdasarkan hasil pemodelan. Pada Gambar 7 juga terlihat terdapat beberapa menu yaitu home, master data dan transaksi.

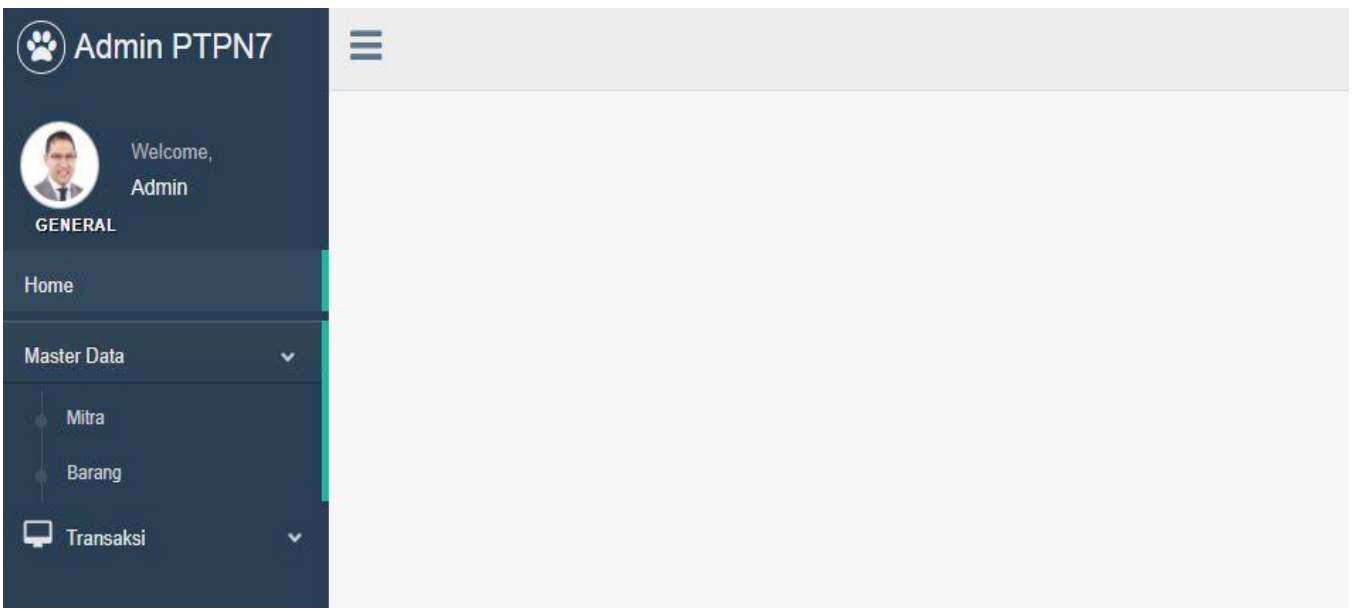

Gambar 7. Tampilan Prototype Sistem Informasi Administrator 
Selain dari tampilan halaman muka administrator seperti yang diperlihatkan pada Gambar 7 maka dapat juga dilihat hasil prototype sistem informasi enterprise resource planning (ERP) PTPN VII dalam proses pengelolaan data barang pada Gambar 8. Dari Gambar 8 dapat dilihat proses pengelolaan data barang terdapat kode barang, nama barang, stok barang dan satuan barang. Selain itu juga terdapat tampilan data barang yang tersimpan pada sistem informasi enterprise resource planning (ERP). Jika dilihat kembali hasil prototype yang ditampilkan merupakan implmentasi dari structure diagram yang diperlihatkan pada Gambar 2.

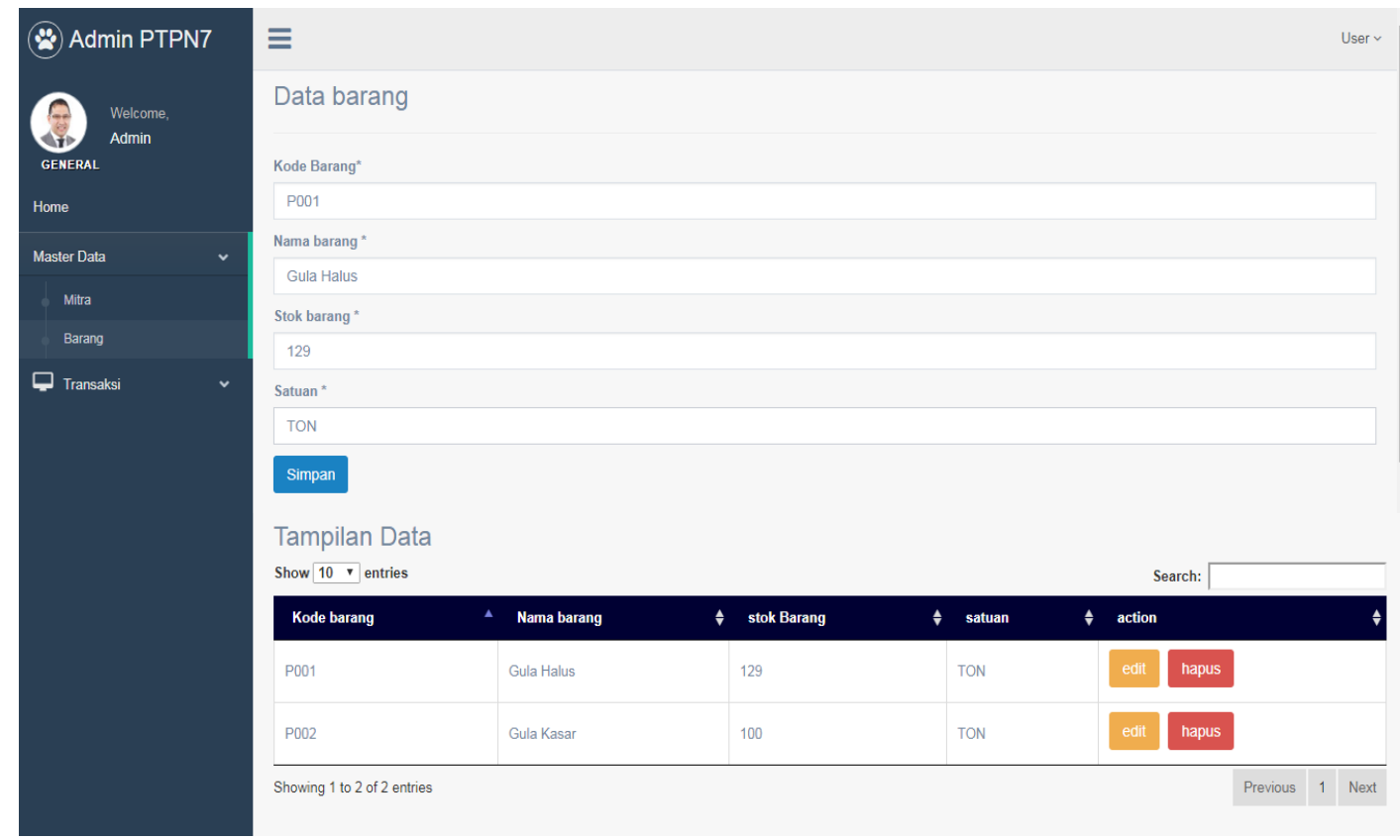

Gambar 8. Tampilan Prototype Sistem Informasi Master Barang

\section{KESIMPULAN}

Sesuai dengan tujuan dan pembahasan yang telah dikemukakan sebelumnya maka dalam proses pemodelan sistem informasi enterprise resource planning (ERP) menggunakan unified modeling language ini dapat simpulkan bebera hal yaitu: (1) pemodelan sistem informasi dapat digambarkan dengan jelas baik secara struktur, tingkah laku dan interaksi. (2) penggunaan unified modeling language sebagai teknik pemodelan memiliki kemampuan untuk menggambarkan bagaimana sistem informasi akan dibentuk melalui diagram kelas, diagram use case dan diagram aktivitas. (3) pembuatan prototype sistem informasi menjadi lebih mudah untuk dilakukan dengan dilakukan pemodelan sehingga proses pengembangan dapat dilakukan dengan tepat sesuai dengan kebutuhan pengguna.

\section{UCAPAN TERIMAKASIH}

Terima kasih disampaikan kepada pihak Jurnal Media Informatika Budidarma yang telah meluangkan waktu untuk melakukan review, editing dan publishing artikel ini. terima kasih juga disampaikan kepada Universitas Bina Darma yang telah mendukung pelaksanaan penelitian ini, tidak lupa juga kami sampaikan terima kasih kepada pihak PTPN VII yang telah memberikan akses dan data sehingga pelenitian ini dapat dilakukan dengan baik sesuai rencana.

\section{REFERENCES}

[1] K. R. Sungkono, R. Sarno, A. J. Ulhaq, M. Taufiqulsa'di, I. N. KurniaSari, and Z. Z. Dinanto, "Pembentukan dan Penerapan Enterprise Resource Planning (ERP) pada UMKM (Usaha Kecil Menengah) Toko Budi dan M-Bisy Mart," SEWAGATI, vol. 3, no. 3, 2019.

[2] A. Prastyo, R. Rispianda, and C. Nugraha, "RANCANGAN SISTEM INFORMASI TERINTEGRASI DI PT. MTE BERBASIS SISTEM ENTERPRISE RESOURCE PLANNING MENGGUNAKAN SOFTWARE ODOO,” REKA Integr., vol. 4, no. 1, 2016.

[3] E. Yulianto and A. Mauludin, "Analisis arsitektur \& fungsional Openbravo 3.0 ERP dan penerapannya menggunakan metode EUP," J. Inf. Vol. IX No, 2017.

[4] A. Syazili, F. Fatoni, and R. Sutejo, "Pemodelan dan Implementasi Perangkat Lunak Berbasis Mobile pada Bina Darma 


\section{JURNAL MEDIA INFORMATIKA BUDIDARMA}

Volume 4, Nomor 2, April 2020, Page 429-436

ISSN 2614-5278 (media cetak), ISSN 2548-8368 (media online)

Available Online at https://ejurnal.stmik-budidarma.ac.id/index.php/mib

DOI 10.30865/mib.v4i2.2022

TV," JISKA (Jurnal Inform. Sunan Kalijaga), vol. 3, no. 3, pp. 62-69, 2019.

[5] L. Wati, R. Kurniati, and M. Mansur, "Perancangan Sistem Aplikasi Pengambilan Keputusan Pemilihan Media Promosi Menggunakan Unifed Modelling Language,” Pros. SISFOTEK, vol. 2, no. 1, pp. 276-284, 2018.

[6] I. Nugroho, H. Listiyono, and S. N. Anwar, "Perancangan Unified Modelling Languageaplikasi Sarana Prasarana Pendukung Pariwisata Kota Semarang,” 2017.

[7] E. F. Wati and A. A. Kusumo, "Penerapan Metode Unified Modeling Language (UML) Berbasis Dekstop pada Sistem Pengolahan Kas Kecil Studi Kasus pada PT Indo Mada Yasa Tangerang,” Syntax J. Inform., vol. 5, no. 1, pp. 24-36, 2017.

[8] S. Suyanto and U. Ependi, "Pengujian Usability dengan Teknik System Usability Scale pada Test Engine Try Out Sertifikasi," MATRIK J. Manajemen, Tek. Inform. dan Rekayasa Komput., vol. 19, no. 1, pp. 62-69, 2019.

[9] U. Ependi, A. Putra, and F. Panjaitan, "Evaluasi tingkat kebergunaan aplikasi Administrasi Penduduk menggunakan teknik System Usability Scale,” Regist. J. Ilm. Teknol. Sist. Inf., vol. 5, no. 1, pp. 63-76, 2019.

[10] A. Hayat, T. Prastica, S. Susanti, and A. Isyamarwati, "Prototipe Sistem Informasi Persediaan Barang Logistik Berbasis Web Dengan Pemodelan UML," Proc. Konf. Nas. Sist. dan Inform., 2015.

[11] A. Syazili and W. Chandra, "Pemodelan UML untuk Perangkat Lunak Antrian pada Klinik Kesehatan," in Seminar Nasional Teknologi Informasi dan Komunikasi (SEMNASTIK), 2018, vol. 1, no. 1, pp. 10-15.

[12] F. Purwaningtias and C. Mukmin, "PEMODELAN ENTERPRISE RESOURCE PLANNING MENGGUNAKAN ODOO PADA Z-TECH KOMPUTER,” KLIK-KUMPULAN J. ILMU Komput., vol. 6, no. 3, pp. 275-283, 2019.

[13] E. W. Fridayanthie and T. Mahdiati, "Rancang Bangun Sistem Informasi Permintaan ATK Berbasis Intranet (Studi Kasus: Kejaksaan Negeri Rangkasbitung),” J. Khatulistiwa Inform., vol. 4, no. 2, 2016.

[14] A. Nayak and D. Samanta, "Model-based test cases synthesis using UML interaction diagrams," ACM SIGSOFT Softw. Eng. Notes, vol. 34, no. 2, pp. 1-10, 2009.

[15] D. Purnomo, "Model Prototyping Pada Pengembangan Sistem Informasi," JIMP-Jurnal Inform. Merdeka Pasuruan, vol. 2, no. 2, 2017 